\title{
ĐỊNH HƯỚNG CÔNG NGHỆ U’U TIÊN TRONG NÔNG NGHIỆP Ở VÙNG BĂC TRUNG BỘ TRONG BỐI CẢNH BIẾN ĐỔI KHÍ́ HẬU
}

\author{
Nguyễn Thị Hoàng Anh', Đỗ Hoài Nam²
}

Tóm tắt: Bắc Trung Bộ là một trong bảy vùng kinh tế được quy hoạch tổng thể về phát triển kinh tế - xã hội. Tuy nhiên, duới tác động của biến đổi khi hậu việc phát triển kinh tế của vùng còn gặp nhiều khó khăn, đặc biệt trong sản xuất nông nghiệp, do đó cần phải có định huớng rõ rệt để áp dụng công nghệ để nâng cao chất lượng sản xuất ngành trồng trọt hiện nay. Nghiên cứu này sư dụng cách tiếp cận đa chiều, phân tích, tổng hợp tài liệu, kết hợp giữa phân tích tùng địa phương với phân tích liên vùng để lự chọn ra nhũng định hướng công nghệ ưu tiên trong nông nghiệp thích hơp cho Bắc Trung Bộ trong bối cảnh biến đổi khỉ hậu. Nhũng định hướng của nghiên cứu này có thể góp phần giúp cho khu vực Bắc Trung Bộ có thêm tầm nhìn và cải tiến trong việc úng dụng khoa hoc công nghệ để sản xuất nông nghiệp hiệu quả nhằm ứng phó tốt hơn với biến đổi khi hậu.

Từ khóa: Bắc Trung Bộ, sản xuất nông nghiệp, khoa học và công nghệ.

Ban Biên tập nhận bài: 08/10/2019 Ngày phản biện xong: 22/11/2019 Ngày đăng bài: 25/12/2019

\section{1. Đặt vấn đề}

Nhằm phát huy lợi thế và khắc phục những tác động tiêu cực tới ngành nông nghiệp, các nước trên thế giới đang tích cực thúc đẩy phát triển nông nghiệp thông minh để hài hòa được lợi ích của kinh tế nông nghiệp với lợi ích của cộng đồng và môi trường, hướng tới mục tiêu phát triển bền vững (Knickel). Ngành Nông nghiệp Việt Nam cũng cần hướng các hệ thống nông nghiệp hiện tại chuyển dịch theo hướng nông nghiệp thông minh để đảm vào vừa đem lại giá trị gia tăng vừa phát triển bền vững như Hình $1[1]$.

Hiệu quả đầu tư vào lĩnh vực nông nghiệp được đo lường bằng hệ số $\mathrm{ICOR}$. So với mức trung bình hơn 6,0 của cả nước và các ngành kinh tế khác thì ngành nông nghiệp vẫn có hiệu quả đầu tư tốt hơn. Mặc dù nhận được ít đầu tư hơn những ngành kinh tế khác song hệ số ICOR của ngành nông nghiệp lại được duy trì ở tỷ lệ tương đối thấp nhưng có xu hướng tăng thể hiện hiệu quả đầu tư giảm dần, trung bình giai đoạn
1989 - 1995 đạt 2,12 nhưng giai đoạn 1996-2000 đã tăng đến 4,05, giai đoạn 2001 - 2010 ổn định và trung bình đạt 3,60 trong khi giai đoạn 2011 đến 2014 lại tăng nhẹ đến 3,84. Giai đoạn 1989 - 2014, ICOR ngành nông nghiệp có xu hướng tăng và đạt trung bình cả giai đoạn 3,34 . Hiệu quả đồng vốn tương đối ổn định trong lĩnh vực này nhưng không đủ sức hấp dẫn các nhà đầu tư tư nhân trong và ngoài nước vượt qua những khó khăn to lớn về kết cấu hạ tầng yếu kém, môi trường đầu tư và công nghiệp hỗ trợ kém được cải thiện Hình 2 [2].

Hiện nay tại Việt Nam, môi trường thuận lợi cho hoạt động sản xuất nông nghiệp thích ứng với biến đổi khí hậu $(\mathrm{BĐKH})$ và giảm phát thải là một trong những ưu tiên hàng đầu. Tuy nhiên, sự xung đột giữa các mục tiêu, mâu thuẫn giữa lợi ích lâu dài của nông nghiệp thông minh và lợi ích trước mắt về tăng trưởng nông nghiệp là những yếu tố hạn chế phát triển nông nghiệp thông minh trên quy mô rộng ở Việt Nam (CGSpace).

'Văn phòng Chuơng trình khoa học và công nghệ cấp quốc gia về tài nguyên môi trường và biến đổi khi hậu, Bộ Tài nguyên và Môi trường

${ }^{2} B \hat{o}$ Khoa hoc và Công nghệ

Email:nthanh1201@gmail.com 


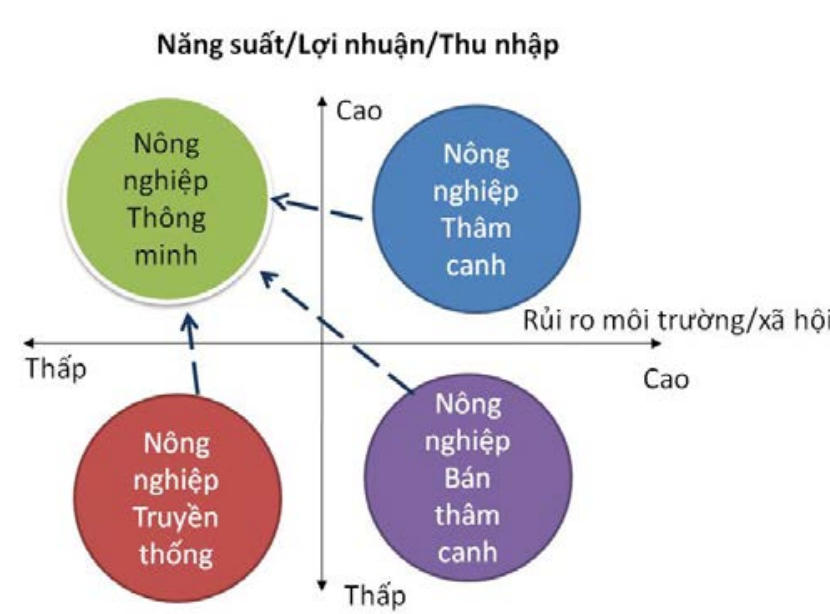

Hình 1. Xu thế phát triển nông nghiệp hiện đại bền vĩng [3-4]

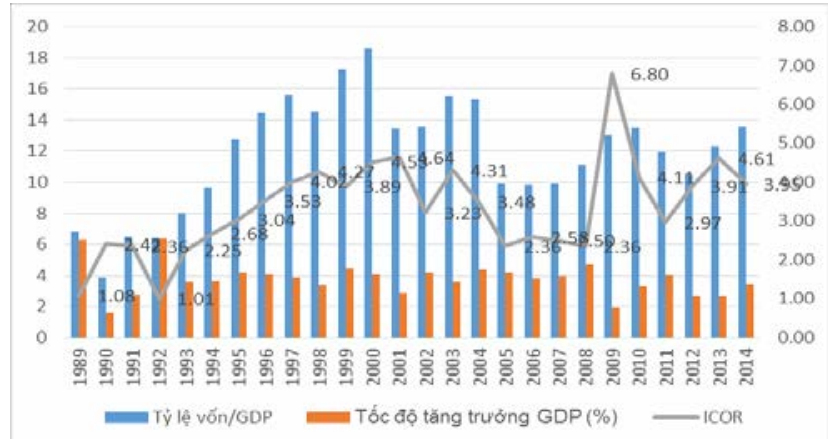

Hình 2. Chỉ số ICOR ngành nông nghiệp Việt Nam giai đoạn 1989 - 2014 (tính toán tù số liệu của Tổng cuc Thống kê các năm tù (1989-2014)[2]

Hiện nay, các điều kiện thời tiết cực đoan (hạn hán, lũ lụt..) liên tiếp xảy ra trong thời gian ngắn khiến sản lượng các thế mạnh nông nghiệp của vùng như cây lương thực (lúa, ngô, sắn), đàn gia súc (trâu, bò) và cây công nghiệp (mía, chè, cao su, hồ tiêu) đều sụt giảm nghiêm trọng. Hơn nữa, việc áp dụng công nghệ vào sản xuất nông nghiệp trong vùng nhìn chung là chưa tương xứng với tiềm năng. Đứng trước bối cảnh mới là biến đổi khí hậu và những hệ lụy của nó, việc ứng dụng nông nghiệp công nghệ cao càng phức tạp hơn nữa, đòi hỏi chúng ta cần chọn lựa ra định hướng công nghệ phù hợp.

Bắc Trung Bộ là một trong bảy vùng kinh tế được Chính phủ giao lập quy hoạch tổng thể về kinh tế xã hội. Do đặc tính địa lý lãnh thổ kéo dài, hẹp bề ngang, kẹp giữa biển Đông và dãy
Trường Sơn; khu vực Bắc Trung Bộ chịu ảnh hưởng rất lớn từ biến đổi khí hậu. Do đó, nghiên cứu sử dụng cách tiếp cận đa chiều, phân tích, tổng hợp tài liệu, kết hợp phân tích từng địa phương với phân tích liên vùng để lựa chọn ra những định hướng công nghệ ưu tiên trong nông nghiệp thích hợp cho Bắc Trung Bộ trong bối cảnh biến đổi khí hậu là cần thiết.

\section{Các tiêu chí lụa chọn định huớng công nghệ ưu tiên}

Việc lựa chọn các định hướng công nghệ ưu tiên trong nông nghiệp cho vùng Bắc Trung Bộ cần thỏa mãn những tiêu chí sau đây: 1) Tiêu chí 1 là phù hợp với xu thế chung của đất nước. Các định hướng công nghệ ưu tiên được chọn cần phù hợp với quan điểm, mục tiêu và chính sách phát triển của Đảng và Chính phủ đã đề ra. Những quyết sách đó là kết quả nghiên cứu của nhiều nhà khoa học và nhà hoạch định uy tín. Hơn nữa, việc chọn định hướng phù hợp với xu thế chung của đất nước sẽ tạo ra khối phát triển đồng nhất giữa các vùng trong cả nước; 2) Tiêu chí 2 là phù hợp với đặc điểm tự nhiên của vùng. Các định hướng công nghệ trong nông nghiệp này cần được điều chỉnh cụ thể cho từng khu vực với vị trí, địa hình, khí hậu; tránh sao chép nguyên bản từ những địa phương khác; 3) Tiêu chí 3 là các định hướng cần phù hợp với điều kiện kinh tế và xã hội. Các định hướng thích hợp cần thỏa mãn các điều kiện về dân cư, giá cả, trình độ, xu hướng của vùng; 4) Tiêu chí 4 là thích hợp trong bối cảnh biến đổi khí hậu, đây là tiêu chí quan trọng cho vùng Bắc Trung Bộ hiện nay. Các định hướng công nghệ ưu tiên cần đảm bảo được tính chủ động cho người nông dân trước diễn biến ngày càng khắc nghiệt của biến đổi khí hậu.

\section{Các định hướng công nghệ ưu tiên trong} sản xuất nông nghiệp vùng Bắc Trung Bộ

3.1. Úng dung công nghệ sinh học trong di truyền để chọn, cải tạo giống

Công nghệ sinh học đóng vai trò quan trọng trong sự phát triển của ngành nông nghiệp. Công việc chọn lựa và cải tạo giống thực chất đã được thực hiện từ hàng ngàn năm nay bằng sự quan 
sát và kinh nghiệm trong thời gian dài, để chọn lựa được những cá thể cây lương thực, cây ăn quả có khỏe mạnh nhất, cho chất lượng và sản lượng tốt nhất. Dưới tác động có chiều hướng tăng của biến đổi khí hậu, kinh nghiệm từ những nước nông nghiệp phát triển chỉ ra rằng định hướng ưu tiên cho ngành công nghệ sinh học là cần thiết. Nhờ công nghệ di truyền, các nhà khoa học đã có thể phân lập, tìm ra những gen quy định sự "khỏe mạnh", "chất lượng" của cây trồng, tạo ra các thay đổi làm tăng/giảm chức năng của gen đó để nó có thể biểu hiện trên cây trồng, phù hợp với mong muốn trong những điều kiện cụ thể.

\section{Tăng cường sản lượng nông sản}

Hiện nay, sản lượng vẫn là tiêu chí được đặt lên hàng đầu ở các cây trồng nông sản. Các gen quy định sản lượng cũng là những gen được nghiên cứu rộng rãi nhất cho tất cả những loài nông sản phổ biến tại Việt Nam. Vấn đề này có thể được tìm thấy, quy trình thí nghiệm có thể lặp lại tại các tạp chí khoa học nông nghiệp có uy tín: Genome Biology, Molecular Systems Biology, Plant Cell, Trends in Plant Science... những nghiên cứu biến đổi lúa nước từ cây trồng $\mathrm{C} 3$ thành cây trồng $\mathrm{C} 4$, giúp tăng lượng các-bon hấp thụ từ đó tăng năng suất từ 30-50\% [1]; hay nghiên cứu rút ngắn quá trình "ngừng không quang hóa" của thực vật (quá trình mà thực vật ngừng quang hợp khi có quá nhiều ánh nắng) giúp tăng hiệu suất quang hợp, từ đó tăng năng suất lên đến $20 \%$ [2]. Như vậy, công việc của những nhà khoa học là chọn lựa gen phù hợp với các loài nông sản vùng Bắc Trung Bộ nói chung hay từng địa hình khí hậu nói riêng, đưa vào thử nghiệm theo từng cấp độ quy mô: trong phòng thí nghiệm, trong nhà xanh, trên đồng ruộng. Những giống lúa được gieo trồng phổ biến ở vùng Bắc Trung Bộ như: HT1, HC95, Thiên U’u 8, Khang Dân, Ma Lâm... đều là những giống lúa lai tạo, không sử dụng đến công nghệ di truyền gen, năng suất đạt 55 tạ/ha (2015). Năng suất kể trên so với các khu vực khác trong nước hay so với các nước trong $\mathrm{ASEAN}$ nằm trong tốp đầu nhưng vẫn còn kém xa so với các cường quốc nông nghiệp. Với việc tạo các giống lúa mới, đặc biệt là các giống lúa $\mathrm{C} 4$, cùng điều kiện thời gian nắng trong ngày nhiều của vùng $\mathrm{BTB}$, hứa hẹn sẽ đưa năng suất tăng lên trên mức 70 tạ/ ha. Quy trình khái quát được trình bày như trong Hình 1 .

\section{Tăng cường chất lượng nông sản}

Bằng việc thay đổi rất nhỏ trong những gen, các quá trình tổng hợp đường, tinh bột sẽ được tăng cường, từ đó nâng cao chất lượng của nông sản. Chất lượng của nông sản có thể kiểm nghiệm được bởi các chỉ số khoa học như độ dẻo, hàm lượng tinh bột trong hạt gạo; lượng tinh bột trong củ khoai tây, khoai lang, sắn...; lượng đường trong củ cải; lượng đường trong táo, mía... Những chỉ số này có những gen tương ứng trên bộ gen của cây quy định. Cụ thể, đối với cây mía đường, chữ đường trung bình ở Việt Nam chỉ đạt 9.7 CCS (đơn vị chữ đường), trong khi trung bình thế giới là 12-13 CCS. Giá mía cũng thay đổi từ vài trăm ngàn đến cả triệu đồng mỗi tấn biến thiên theo chữ đường. Chỉ số CCS trong mía thay đổi không chỉ nhờ cách chăm sóc mà còn phụ thuộc vào giống mía. Khả năng tích tụ đường trong mía được quy định bởi các enzym trong con đường gluconeogenesis, việc thay đổi các gen trong con đường này sẽ làm tăng lượng đường được thu thập trong thân mía, theo nghiên cứu của Menossi và cộng sư năm 2008 [5-6].

Khả năng chống chịu ở đây có thể kể đến như chống hạn, chống úng, chống sâu và chống bệnh. Với việc chống hạn và chống úng hay ngập nước, có thể thay đổi các gen liên quan đến việc sử dụng nước của cây trồng (tùy vào tình hình thời tiết mỗi vùng). Khả năng chịu úng ngập cho những vùng ven biển dễ ngập lụt. Cây trồng có thể chịu ngập dưới nước từ 2-3 ngày đủ thời gian cho nước lũ rút, giảm thiểu thiệt hại. Theo cơ sở dữ liệu PlantGDB, các nhà khoa học đã tìm ra hơn 100 gen có thể thay đổi để giảm lượng nước hấp thụ (từ 20-70\%) trong điều kiện ngập úng cho Oryza sativa và Oryza glaberrima (hai loài lúa nước phổ biến). Khả năng chịu hạn cho những vùng phía Tây với khí hậu khô nóng, lượng mưa ít hay những thời điểm hạn hán do biến đổi khí hậu. Khả năng chịu mặn dành cho 
những vùng ven biển dễ bị xâm thực vì nước biển dâng do BĐKH. Nhiều nghiên cứu cho thấy đã có thể cải tạo được những giống lúa chịu độ mặn lên tới 10-12\%o. Khả năng chịu phèn chua cũng cần thiết cho cây trồng, nhất là lúa nước.
Nếu bị phèn trong thời kỳ làm đòng sẽ làm lúa chậm phát triển, đòng nhỏ, trỗ không tập trung và có thể bị nghẹn đòng, bông ngắn, hạt lép nhiều, năng suất và chất lượng đều giảm, lợi nhuận của nông dân thấp.

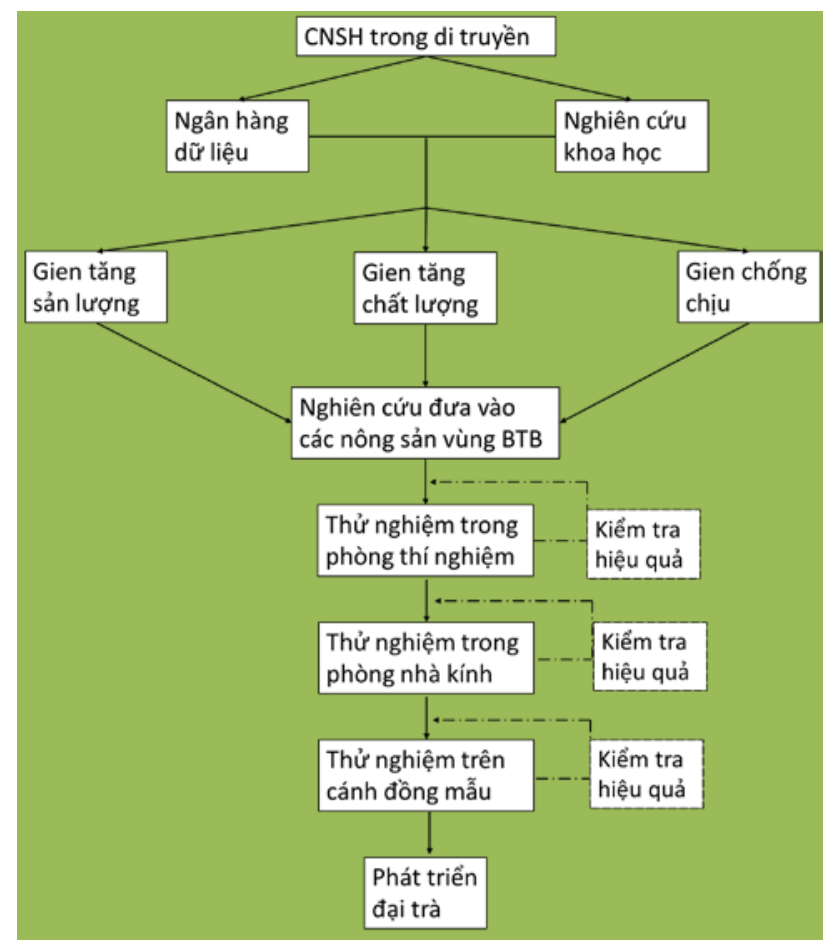

Hình 3. Biểu đồ quy trình áp dụng công nghệ sinh học trong di truyền trong chọn, cái tạo giống nông sản [5]

Đối với khả năng chống sâu bệnh, ta có thể hiểu hệ thống miễn dịch của cây trồng cũng được quy định bởi những gen tương ứng. Vi khuẩn Bacillus thuringensis $(\mathrm{Bt})$ được biết đến từ lâu với khả năng diệt sâu bệnh mà không gây nguy hại tới động vật hay con người. Nhờ thành tựu của kỹ thuật vật chất di truyền tái tổ hợp, các nhà khoa học đã tìm được phương pháp lợi dụng các gen tạo ra độc tố lên côn trùng của $B t$ để đưa vào nông sản tạo hiệu quả kháng côn trùng. Quy trình cơ bản được trình bày trong Hình 3 . Như vậy, để tạo được nguồn giống phong phú, tính năng tốt: đạt sản lượng cao, chất lượng vượt trội, và kháng hạn hán, ngập úng, sâu bệnh hại, định hướng phát triển công nghệ trong nông nghiệp theo hướng ứng dụng công nghệ sinh học di truyền ở vùng Bắc Trung Bộ là hết sức có ý nghĩa trong thực tại và tương lai.

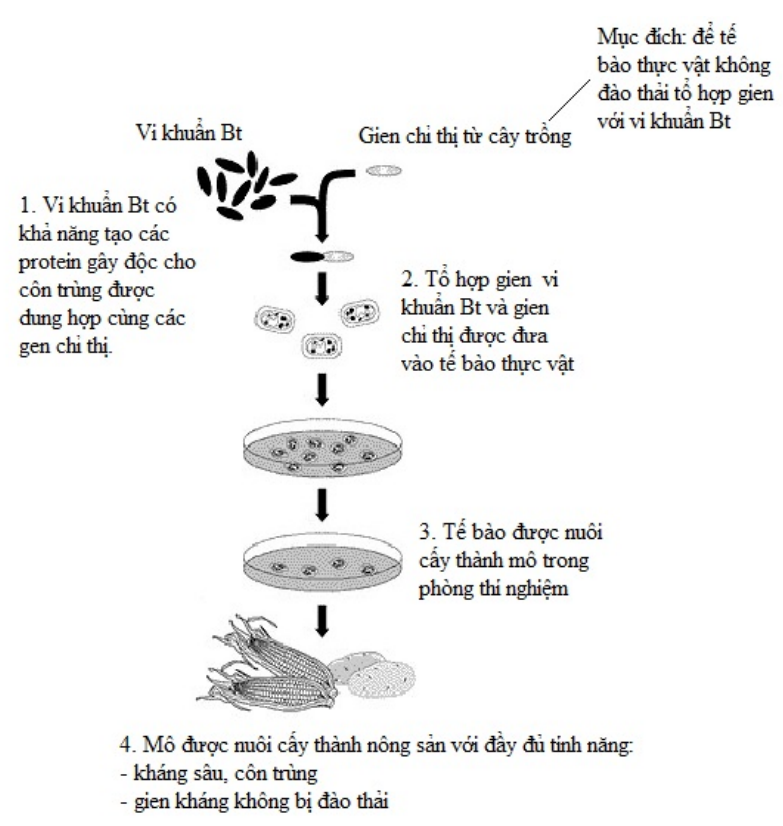

Hình 4. Sủ dụng công nghệ gen tạo cây trồng kháng côn trùng [5] 


\section{2. Úng dụng công nghệ sinh học trong} nuôi cấy mô, nhân giống số lượng lớn

Giống là một trong những đặc điểm quan trọng nhất ảnh hưởng đến giá trị của nông sản. Bên cạnh việc tạo và nâng cấp loại giống, thì việc nhân những giống có chất lượng tốt đó lên và phát triển thành cây con mà sạch bệnh và giữ nguyên những phẩm chất tốt cũng là một định hướng công nghệ cần nhắm tới của vùng Bắc Trung Bộ có một nền nông nghiệp hiện đại. Kỹ thuật nuôi cấy mô tế bào thực vật dựa trên thực tế là nhiều tế bào thực vật có khả năng tái sinh thành cây hoàn chỉnh. Với kỹ thuật nuôi cấy mô, khả năng nảy mầm và tỷ lệ sống sót đều được tăng cường. Thời gian trở thành cây con cũng được rút ngắn, và chất lượng của giống (tăng sản lượng, năng suất, chống sâu bệnh...) được đảm bảo do điều kiện môi trường nuôi cấy đã được nghiên cứu phù hợp. Các kỹ thuật khác nhau trong nuôi cấy mô tế bào thực vật có thể cung cấp những lợi thế nhất định so với phương pháp nhân giống truyền thống, bao gồm: Tạo ra chính xác số cây nhân bản giúp tạo ra các loại hoa, quả chất lượng cao hoặc có những tính trạng mong muốn khác; Tạo ra các cây trưởng thành một cách nhanh chóng; Tạo ra hàng loạt các cây mà không cần đến hạt hoặc quá trình thụ phấn để tạo hạt; Tái sinh cây hoàn chỉnh từ các tế bào thực vật đã được biến đổi gen; Tạo ra các cây trong điều kiện vô trùng, để có thể vận chuyển mà hạn chế tối đa khả năng phát tán bệnh, sâu bệnh hoặc các nhân tố gây bệnh; Có thể tạo ra các cây từ hạt mà nếu không có nuôi cấy mô thì thường có tỷ lệ nảy mầm thấp hoặc sinh trưởng yếu, ví dụ: hoa lan hoặc cây nắp ấm; Làm sạch các cây bị nhiễm virus nhất định hoặc các nhân tố lây nhiễm khác và nhân nhanh các cây này như là nguồn nguyên liệu sạch phục vụ đồng ruộng và nông nghiệp; Đối với vùng Bắc Trung Bộ, do đặc điểm thời tiết bất thường, việc sử dụng nuôi cấy mô để nhân giống còn mang lại lợi thế tránh thời gian điều kiện thời tiết bất lợi như thời điểm khô hạn, bão lũ..., đồng thời đưa ra cây con đã phát triển có sức chống chịu cao hơn [5]. Quy trình cơ bản của kỹ thuật nuôi cấy mô được trình bày trong Hình 4 Kết quả nghiên cứu cho thấy rằng, kỹ thuật nuôi cấy mô để nhân giống số lượng lớn có nhiều ưu điểm tại vùng Bắc Trung Bộ, tuy nhiên chưa thể áp dụng lên quy mô rộng do hạn chế về cơ sở vật chất, công nghệ, và nhân lực chất lượng cao.

Trong đánh giá này, chúng tôi cũng tiến hành phân tích rõ ràng những yêu cầu về cơ sở, công nghệ và nhân lực của việc áp dụng kỹ thuật nuôi cấy mô, để làm sáng tỏ rằng đây là một định hướng công nghệ trong nông nghiệp cần thiết cho tương lai gần, và hoàn toàn khả thi ở vùng Bắc Trung Bộ trong tình trạng biến đổi khí hậu như hiện nay như sau: Về cơ sở vật chất, kỹ thuật nuôi cấy mô yêu cầu một phòng thí nghiệm thông thường, đảm bảo tiêu chuẩn an toàn sinh học cấp 1 , cùng nhà nuôi cấy với diện tích phụ thuộc vào công suất cần đảm nhận (theo ước tính, $100 \mathrm{~m} 2$ có thể sản xuất sinh khối giống cho 500 ha cây trồng ngắn ngày và 300 ha cây trồng lâu năm). Về công nghệ, kỹ thuật nuôi cấy mô không phải là kỹ thuật mới hay phức tạp, nó đã được áp dụng trên thế giới nhiều thập kỷ nay và cũng đã có những tổ chức, doanh nghiệp thực hiện tại vùng Bắc Trung Bộ như: Công ty lâm nghiệp Tiền Phong tại Thừa Thiên - Huế, Trung tâm ứng dụng tiến bộ KHCN tại Hà Tĩnh...; Về nhân lực, một cơ sở nuôi cấy mô cần 2-3 nghiên cứu viên trình độ đại học trở lên và $4-5$ kỹ thuật viên trình độ trung cấp. Với xu thế phát triển hiện nay, nguồn nhân lực chất lượng cao cho định hướng phát triển công nghệ này ở Bắc Trung Bộ sẽ được đảm bảo.

\section{3. Úng dụng công nghệ sinh hoc trong điều chế sản phẩm hỗ trợ ngành trồng trọt}

Với việc sử dụng phân bón sinh học, nông sản có thể phát triển tốt mà không làm thoái hóa đất, không chứa bất kỳ chất hóa học nào có thể gây hại đến môi trường, con người và các sinh vật khác. Các loại phân bón sinh học cố định đạm thông thường có nguồn gốc từ các vi sinh vật như: Rhizobium (dùng cho các cây họ đậu), Azotobacter (thường dùng trên ngũ cốc, khoai, mì), Azospririlium (tốt cho cao lương, ngô, mía và lúa nước) và tảo lam (dùng trên ruộng lúa 
nước, có khả năng tổng hợp tới $60 \mathrm{~kg}$ ni-tơ/ha/vụ và nhiều hợp chất hữu cơ khác). Một số loại vi sinh vật khác, như vi sinh vật hòa tan phốt-phát như Pantoea agglomerans P5 hay Pseudomonas putida $\mathrm{P} 13$ có khả năng hòa tan phốt-phát không tan trong đất.

Thuốc bảo vệ thực vật (BVTV) sinh học là tên gọi chung của những hợp chất có sẵn trong tự nhiên: trong vi sinh vật, trong thực vật mà có khả năng bảo vệ cây trồng khỏi những mối nguy hại như sâu, bệnh, côn trùng, cỏ dại... Những năm gần đây, cụm từ "thuốc BVTV sinh học" được coi như song hành với việc phát triển nguồn tài nguyên thiên nhiên cho sự phát triển bền vững của nông nghiệp. Các loại thuốc BVTV từ sinh học lại được phân ra làm 3 loại chính dựa vào nguồn gốc của chúng: 1) Các thuốc BVTV từ vi sinh vật: vi khuẩn, nấm, giun tròn, trùng đơn bào... Có nhiều loài vi sinh vật là thiên địch của các côn trùng, nấm hay cỏ dại, chỉ cần 1 lượng nhỏ những vi sinh vật này bám trên thực vật có thể phát triển gây chết diện rộng cho các vật hại kể trên; 2) Các thuốc BVTV sinh hóa: hay là những chất hóa học nhưng được chiết xuất từ các vật sống chủ yếu từ thực vật như củ tỏi, thân sả, hạt nêm, lá cây thanh hao...; Các thuốc BVTV từ vật chất di truyền: là những vật chất di truyền có kích thước rất nhỏ, được thiết kế sẵn để có thể đi vào bên trong cơ thể sâu bệnh và biến đổi bộ gen của chúng, giết chết hoặc làm chúng dễ bị tổn thương bởi các thuốc BVTV khác.

Dựa vào Bảng 1 , ta có thể dễ dàng nhận thấy ưu điểm vượt trội của các sản phẩm hỗ trợ trồng trọt có nguồn gốc từ sinh học, từ hiệu quả tác dụng đến hiệu quả kinh tế và giá thành. Bảng 1 cũng chỉ ra giá thành của những sản phẩm từ sinh học sẽ giảm nếu được sản xuất tại địa phương. Tuy nhiên, trở ngại lớn nhất đối với vùng Bắc Trung Bộ trong việc tiếp cận những sản phẩm này là công nghệ. Vì vậy, việc đưa ứng dụng công nghệ sinh học vào sản xuất các sản phẩm hỗ trợ trồng trọt từ sinh học là một định hướng công nghệ ưu tiên cần thiết cho vùng.

\section{Bảng 1. So sánh một số đặc điểm của sản phẩm hỗ trợ trồng trọt có nguồn gốc hóa hoc và sinh hoc}

\begin{tabular}{|c|c|c|}
\hline & Các sản phẩm nguồn gốc hóa học & Các sản phẩm nguồn gốc sinh học \\
\hline Số đầu sản phẩm & Rất nhiều nhưng đang bị hạn chế dần & Còn ít nhưng số lượng tăng dần \\
\hline $\begin{array}{l}\text { Dư lượng thuốc } \\
\text { trên cây trồng }\end{array}$ & $\begin{array}{l}\text { Nhiều: đều là các hóa chất, không an } \\
\text { toàn cho người tiêu dùng }\end{array}$ & $\begin{array}{l}\text { Ít đến không để lại: là các hợp chất từ } \\
\text { sinh học, an toàn }\end{array}$ \\
\hline Hiệu quả & $\begin{array}{l}\text { Trung bình: Vùng hiệu quả rộng. } \\
\text { Thời gian hiệu quả ngắn, phải lặp lại } \\
\text { nhiều lần trong một vụ }\end{array}$ & $\begin{array}{l}\text { Tốt hơn: Đặc hiệu cao, thời gian hiệu } \\
\text { quả dài, có thể kéo dài tới vụ sau }\end{array}$ \\
\hline $\begin{array}{l}\text { An toàn với môi } \\
\text { trường }\end{array}$ & $\begin{array}{l}\text { Độc hại, tồn dư trong đất và trong } \\
\text { thùng chứa là mối nguy hại lớn tới } \\
\text { môi trường }\end{array}$ & Hầu như an toàn với môi trường \\
\hline $\begin{array}{l}\text { An toàn với sinh } \\
\text { vật khác }\end{array}$ & $\begin{array}{l}\text { Nguy hiểm tới sinh vật khác và con } \\
\text { người }\end{array}$ & $\begin{array}{l}\text { An toàn với con người, một số sinh } \\
\text { vật khác }\end{array}$ \\
\hline $\begin{array}{l}\text { Đối với các tiêu } \\
\text { chuẩn và hàng } \\
\text { rào xuất khẩu }\end{array}$ & Rất nghiêm ngặt & Được nới lỏng hơn \\
\hline $\begin{array}{l}\text { Sử dụng tại vùng } \\
\text { BTB }\end{array}$ & Trên $90 \%$ & Chỉ đạt chưa tới 10\% \\
\hline Giá thành & Thông thường & Rẻ hơn nếu được địa phương hóa \\
\hline $\begin{array}{l}\text { Thái độ của } \\
\text { người tiêu dùng }\end{array}$ & Không ủng hộ, nghi ngại & Ủng hộ \\
\hline
\end{tabular}




\section{4. Úng dụng công nghệ tự động hóa vào ngành trồng trọt}

Tự động hóa hoặc điều khiển tự động, là việc sử dụng nhiều hệ thống điều khiển cho các thiết bị hoạt động như máy móc, xử lý, bảng mạch; chỉ đạo và ổn định của máy tự hành và các ứng dụng khác với sự can thiệp của con người tối thiểu hoặc giảm. Lợi ích lớn nhất của tự động hóa là nó tiết kiệm lao động, tuy nhiên, nó cũng được sử dụng để tiết kiệm năng lượng và nguyên vật liệu và nâng cao chất lượng với độ chính xác cao. Trong lĩnh vực nông nghiệp, tự động hóa được ứng dụng vào những máy gieo trồng, hái lượm; các hệ thống tưới tiêu, phun thuốc, bón phân tự động; các hệ thống cảm biến lượng nước, tầm soát dịch bệnh và tính toán ra biện pháp phù hợp; các hệ thống chọn lọc sau thu hoạch... Ở vùng Bắc Trung Bộ, tự động hóa nông nghiệp mới phổ biến trong nông dân ở những máy cày, bừa, lên luống hay gặt, đập... những hệ thống tưới tiêu hay thu hoạch tự động vẫn còn hạn chế. Trong bối cảnh biến đổi khí hậu tại vùng Bắc Trung Bộ như hiện nay, việc định hướng công nghệ ưu tiên cho tự động hóa là hoàn toàn thiết yếu: những hệ thống gieo trồng, thu hoạch sẽ giảm đáng kể thời gian, giúp nông dân tránh được những thiên tai; hệ thống cảm biến cùng tưới tiêu tự động sẽ có thể giảm được lượng nước sử dụng, chống chịu với hạn hán.

Úng dụng công nghệ tự động hóa trong gieo trồng, chăm sóc và thu hoạch

Vùng Bắc Trung Bộ có diện tích đất nông nghiệp chiếm tới hơn $28 \%$ diện tích đất nông nghiệp của cả nước và trên $80 \%$ diện tích đất tự nhiên của vùng, trong đó diện tích đất đồi núi cũng chiếm tỷ lệ không nhỏ. Chính vì vậy việc gieo trồng, chăm sóc và thu hoạch trên diện tích đất lớn tốn rất nhiều công sức, thời gian và chi phí cho người nông dân. Do đó, việc ứng dụng công nghệ tự động hóa trong gieo trồng, chăm sóc và thu hoạch được xem như là một định hướng ưu tiên cho vùng Bắc Trung Bộ hiên nay. Các công nghệ cụ thể như các máy gieo trồng (máy làm đất, lên luống, máy gieo hạt, máy trồng cây con), hệ thống chăm sóc (hệ thống tưới tiêu tự động, máy phun thuốc bảo vệ thực vật, phân bón tự động) vầ các máy thu hoạch (máy gặt đập liên hợp, máy thu hoạch rau màu).

Ưu điểm vượt trội nhất của các công nghệ tự động hóa kể trên là tiết kiệm được công sức và thời gian lao động. Điều này hết sức quan trọng trong tình hình biến đổi khí hậu bởi những biến động thời tiết bất thường có thể ảnh hưởng đến sản lượng cũng như chất lượng nông sản, việc rút ngắn thời gian của những công đoạn gieo trồng, chăm sóc, thu hoạch nói trên sẽ hạn chế được những mất mát cho nhà nông.

Úng dụng công nghệ tự động hóa trong phân loại sản phẩm nông sản

Việc phân loại nông sản rất được quan tâm tại các nước có ngành nông nghiệp hiện đại. Theo nghiên cứu của các nhà kinh tế học Đại học Tokyo, Nhật bản, việc phân cấp và sắp xếp các sản phẩm đồng dạng giúp tăng giá trị kinh tế nông sản lên đến $15 \%$. Thí dụ, gạo từ cùng một giống lúa ở Nhật Bản cũng được phân theo mức độ xay sát của chúng: gạo để nấu ăn thông thường sẽ chỉ xay sát 30\% hạt thóc có giá rẻ nhất, gạo xay sát $50 \%$ thể tích thì được dùng trong những món ăn cao cấp và gạo xay sát đến $70 \%$ thể tích, chỉ còn giữ lại nhân tinh bột thì được sử dụng làm rượu gạo hảo hạng. Tuy nhiên, người nông dân không thể nào sàng lọc bằng thủ công từng hạt gạo, từng trái cây được. Do đó, việc ứng dụng công nghệ tự động hóa vào phân loại nông sản cũng là một trong những định hướng quan trọng trong trồng trọt với mục tiêu kiểm định, phân cấp nông sản để tăng giá trị và sản lượng nông sản xuất khẩu cũng như phục vụ người tiêu dùng ngày càng khó tính trong nước. Việc sử dụng công nghệ phân loại thích hợp nào sẽ cần dựa vào loại nông sản và mục đích áp dụng [6-11].

\section{5. Ưng dụng công nghệ thông tin vào ngành trồng trọt}

Để khai thác có hiệu quả hơn nữa tiềm năng của vùng trong phát triển kinh tế nông nghiệp, nông thôn, nhiều năm trở lại đây, vùng Bắc Trung Bộ đã tích cực ứng dụng công nghệ thông tin vào phát triển nông nghiệp, nông thôn, nông 
dân (tam nông) và được đánh giá cao, mang lại hiệu quả đáng kể. Tuy nhiên, nếu xét trên phương diện nền nông nghiệp tiên tiến, những ứng dụng này còn rất khiêm tốn khi chỉ dừng lại ở việc quảng bá sản phẩm quy mô nhỏ, hay đào tạo trình độ mức độ rải rác.

Úng dụng công nghệ thông tin trong hỗ trợ trồng trọt vùng Bắc Trung Bộ cần phải tiến hành thúc đẩy các giải pháp sau: 1) Cơ sở dữ liệu cơ bản nông nghiệp và nông thôn các các địa phương có thể được xây dựng với mục đích tạo ra một cơ sở dữ liệu trên nền tảng web đơn giản, thuận lợi cho việc truy cập thông tin, thiết thực với nhiều nhóm người dùng; 2) Sử dụng các thông tin liên lạc không dây giúp loại bỏ sự cần thiết cho việc lắp đặt cáp đồng trục, giúp liên lạc tầm xa hoặc thực tế không thể lắp đặt hệ thống dây dẫn. Một số ứng dụng cảm biến không dây phổ biến như theo dõi sự di chuyển ảnh hưởng tới mùa màng và vật nuôi; tình trạng nước tưới; phát hiện hóa học, sinh học; tính toán trong nông nghiệp; kiểm tra môi trường không khí, đất trồng, biển; phát hiện cháy rừng; nghiên cứu khí tượng và địa lý; phát hiện lũ lụt; vẽ bản đồ sinh học phức tạp của môi trường và nghiên cứu ô nhiễm môi trường, kiểm tra các điều kiện môi trường. Mạng có thể được dung để đo độ ẩm ở từng khu vực trong trang trại hay lượng mưa ở những khu vực khác nhau. Các nút mạng được bố trí tại các cánh đồng khác nhau để thu thập các thông tin về môi trường (nhiệt độ, độ ẩm, ánh sáng...) sau đó chuyển dữ liệu về người nông dân (Hình 5). Trong dự báo cháy rừng, mỗi nút mạng sẽ gắn một cảm biến đo nhiệt độ, độ ẩm của không khí phân tán trong rừng, Mỗi nút cảm biến có thể thu thập nhiều thông tin khác nhau liên quan đến cháy như nhiệt độ, khói ...Các dữ liệu thu thập được truyền tới trung tâm điều khiển để giám sát, phân tích, phát hiện và cảnh báo cháy sớm ngăn chặn thảm họa cháy rừng (Hình 6). Trong nuôi trồng thủy sản, mạng cảm biến không dây có thể được dùng để quan trắc nồng độ ôxy, độ pH trong các hồ nuôi trồng hải sản, khi đó có thể điều khiển tự động các quạt đạp nước cung cấp ôxy và thông báo cho người quản lý biết tình hình về nguồn nước hiện tại trong ao; 3) Trong nông nghiệp, việc sử dụng các hệ thống định vị toàn cầu đem lại lợi ích trong địa lý, lập bản đồ, khảo sát biến động không gian; 4) Hệ thống thông tin địa lý (Geographic Information System-GIS), trong sản xuất nông nghiệp, GIS có thể sử dụng để giám sát mùa vụ cho từng cây trồng. Việc dự báo có thể bằng cách xem xét khí hậu của vùng hoặc bằng cách theo dõi sự sinh trưởng và phát triển cây trồng, sẽ dự đoán được sự thành công của mùa vụ; 5) Việc sử dụng kỹ thuật ảnh viễn thám kết hợp với kỹ thuật GIS, cùng phương pháp thống kê hay nội suy không gian, đã được ứng dụng trong nhiều nghiên cứu về sự phân bố không gian các đặc tính tự nhiên ở nhiều nước trên thế giới [5-9]. Định hướng công nghệ viễn thám cho vùng Bắc Trung Bộ cần đi vào vi mô như viễn thám đất đai, khí tượng, côn trùng...cho từng xã, từng vùng canh tác riêng biệt để nông dân nắm bắt được cụ thể những gì diễn ra trên cánh đồng của mình.
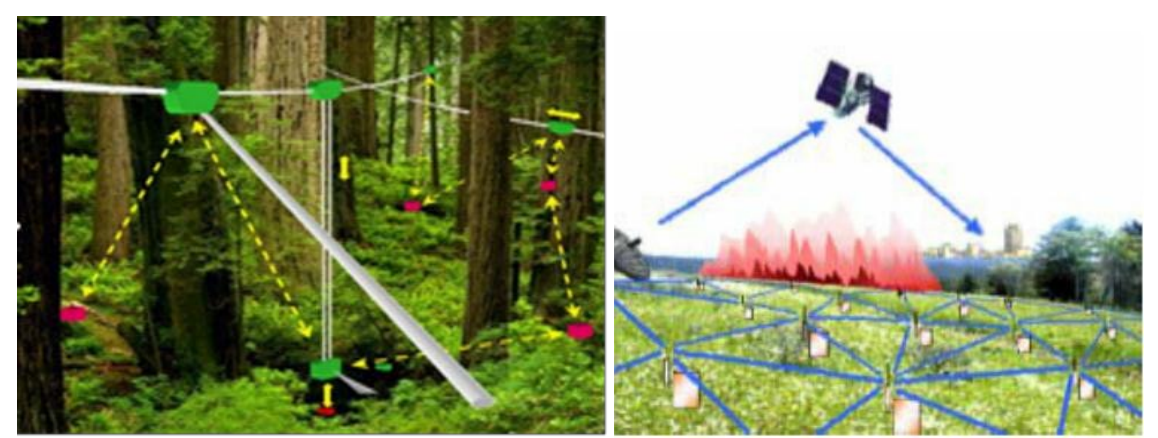

Hình 5. Hệ thống mạng không dây đo ẩm độ ngoài đồng và quan trắc dụ báo cháy rùng 


\section{BÀI BÁO KHOA HỌC}

Thương mại sản phẩm là một bước quan trọng trong ngành nông nghiệp. Với sự bùng nổ của công nghệ thông tin, nông dân hiện đại không chỉ bán hàng tại các chợ truyền thống hay bán buôn cho thương lái mà còn có thể thương mại sản phẩm qua mạng trực tuyến. Dựa trên những điểm mạnh và tồn tại trong kể trên, đề xuất của chúng tôi muốn hướng đến trong định hướng công nghệ thương mại điện tử của vùng là: 1) Xây dựng cở sở dữ liệu các sản phẩm đặc sản của từng tỉnh: ví dụ như Thanh Hóa có mía Kim Tân, dừa Hoằng Hóa, rau má; Nghệ An có bưởi hồng Quang Tiến, ớt cay Tương Dương; Hà Tĩnh có bưởi Phúc Trạch, cam Hương Khê; Quảng Bình có khoai deo Hải Ninh; Quảng Trị có tiêu Cùa, sâm Ngọc Linh; Thừa Thiên-Huế có thanh trà, vải... Quảng bá những sản phẩm này trực tuyến với những điểm vượt trội của chúng so với nông sản cùng loại ở địa phương khác; 2) Xây dựng mạng lưới mua bán, trực tiếp từ nông dân tới người tiêu dùng: tiện lợi cho người tiêu dùng, trong khi người nông dân được nhận hoàn toàn lợi nhuận.
Đối với việc ứng dụng công nghệ thông tin trong đào tạo trực tuyến thể hiện nhiều ưu điểm vượt trội trong đào tạo đã làm thay đổi mạnh mẽ quá trình tự học do khả năng cá nhân hóa cũng như đáp ứng hiệu quả các hoạt động học tập của người học. Trong nghiên cứu này, đề xuất định hướng ưu tiên công nghệ thông tin trong đào tạo trực tuyến với mục tiêu ứng dụng để đào tạo các kỹ thuật nông nghiệp mới cho nông dân vùng Bắc Trung Bộ: 1) Thiết lập địa điểm học trực tuyến tập trung tại các nhà văn hóa làng, xã với đường truyền và thiết bị thu, phát hình ảnh; 2) Tổ chức các lớp phổ biến, tập huấn kỹ thuật mới thông qua ứng dụng CNTT. Nông dân có thể tương tác trực tiếp với người giảng dạy thông qua bộ thu, phát hình ảnh.

Cơ sở dữ liệu (CSDL) cơ bản nông nghiệp và nông thôn các các địa phương có thể được xây dựng với mục đích tạo ra một cơ sở dữ liệu trên nền tảng web đơn giản, thuận lợi cho việc truy cập thông tin, thiết thực với nhiều nhóm người dung (Hình 6).

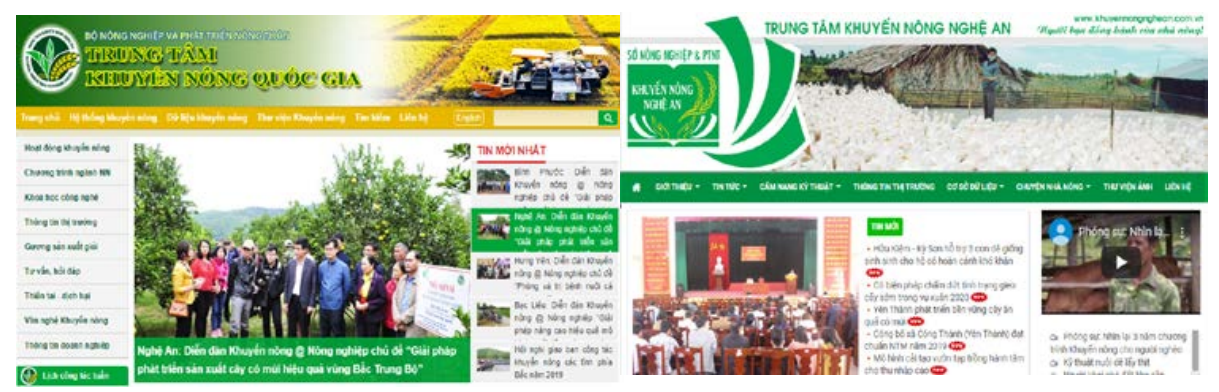

Hình 6. Giao diện trang web cơ sở dĩ liệu nông nghiệp

Số liệu thu thập, lưu trữ trong CSDL từ nguồn số liệu thống kê chính thức, tư liệu kinh tế xã hội các tỉnh/thành phố và số liệu điều tra nông nghiệp nông thôn, mức sống dân cư của Tổng cục Thống kê và nguồn từ các cơ quan, địa phương khác được tổ chức thành các bảng số liệu, với rất nhiều chỉ tiêu có thể đưa ra theo các mẫu báo cáo khác nhau. Số liệu cập nhật vào cơ sở dữ liệu từ nhiều năm, sẽ tiếp tục được cập nhật theo tần suất hàng năm, tương ứng với mỗi nguồn số liệu. Thông tin có thể được tìm kiếm, trích rút và lập báo cáo theo giai đoạn nhất định và được so sánh theo theo mốc thời gian.

\section{Kết luận}

Sự gia tăng các hiện tượng thời tiết cực đoan như lũ lụt, các đợt lạnh tăng cường, hạn hán tại khu vực Bắc Trung Bộ cho thấy biểu hiện của biến đổi khí hậu ngày càng rõ rệt hơn. Chuyển đổi thực hành sản xuất nông nghiệp truyền thống sang hướng thích ứng với biến đổi khí hậu $(\mathrm{BĐKH})$ và bền vững với môi trường sẽ giúp ngành nông nghiệp khắc phục được những thách thức liên quan đến biến đổi khí hậu.

Để duy trì sản xuất nông nghiệp trong bối 
cảnh rủi ro khí hậu ngày càng gia tăng, nhiều thực hành nông nghiệp đã được xác định là có khả năng thích ứng tốt với $\mathrm{BĐKH.} \mathrm{Các} \mathrm{thực}$ hành này bao gồm: quản lý nguồn nước và thủy lợi thông minh; áp dụng các giống cây trồng cải tiến; sản xuất nông lâm kết hợp; xen canh cây trồng; quản lý đất đai bền vững; xử lý chất thải nông nghiệp (tích hợp công nghệ khí sinh học vào chăn nuôi); và cải tiến các dịch vụ thông tin khí hậu nông nghiệp. Tuy nhiên, mức độ áp dụng các công nghệ nông nghiệp thông minh nhìn chung vẫn ở mức thấp hoặc trung bình tại khu vực Bắc Trung Bộ.

Nghiên cứu này đã phân tích kỹ các nghiên cứu trước đây đồng thời các định hướng lựa chọn đều được sàng lọc qua các tiêu chí phù hợp với đặc điểm của vùng Bắc Trung Bộ trong bối cảnh biến đổi khí hậu. Kết quả nghiên cứu này sẽ có ý nghĩa thực tiễn với các nhà quản lý tại địa phương. Nghiên cứu tại vùng Bắc Trung Bộ cũng là những đề xuất ban đầu, hứa hẹn làm tiền đề ứng dụng nghiên cứu ở các địa phương khác trên cả nước.

Lời cám ơn: Kết quả của bài báo là một phần kết quả của đề tài cấp quốc gia "Nghiên cứu, ưng dụng công nghệ tiên tiến phục vu sản xuất nông nghiệp cho các vùng đồi núi Bắc Trung Bộ thích ưng với biến đổi khi hậu (BĐKH.01/16-20)".

\section{Tài liệu tham khảo}

1. Nguyễn Xuân Trạch (2018), Hiện đại hóa nông nghiệp ở Việt Nam: thách thức và giải pháp. Khoa Chăn nuôi - Học viện Nông nghiệp Việt Nam.

2. Lưu Tiến Dũng (2016), Phát triển nông nghiệp bền vũng ở Việt Nam trong bối cảnh mới của họi nhập kinh tế quốc tế. Trường Đại học Lạc Hồng.

3. Smithers, J., Alison, B.P., (2001), Technology innovation as a strategy for climate adaptation in agriculture. Applied Geography, 21, 175-197.

4. Zhu, X., Rebecca, C., Jeremy, H., Alicia, Q., Juan, T., (2011), Technologies for Climate Change Adaptation: Agriculture Sector, TNA Guidebook Series, pp. 2019.

5. Phạm Thị Thanh Hương (2019), Đề tài cấp quốc gia "Nghiên cứu, ưng dụng công nghệ tiên tiến phục vu sản xuất nông nghiệp cho các vùng đồi núi Bắc Trung Bộ thích ứng với biến đổi khí hậu”, mã số BĐKH.01/16-20.

6. Knickel, K., Ashkenazy, A., Chebach, T. C., Parrot, N., (2017), Agricultural modernization and sustainable agriculture: contradictions and complementarities. International Journal of Agricultural Sustainability, 15 (5), 575-592.

7. CGSpace. Nông nghiệp thông minh thich ưng với biến đổi khi hậu (CSA) ở Việt Nam. https://cgspace.cgiar.org/

8. Kamata, N., Liebhold, A., (2000), Are population cycles and spatial synchrony a universal characteristic of forest insect populations?. Population Ecology, 42 (3), 205-209.

9. Dự án lúa C4. Viện nghiên cứu gạo quốc tế, IRRI.

10. Kromdijk, J., Glowacka, K., Leonelli, L., Gabilly, S.T., Iwai, M., Niyogi, K.K., Long, S.P., (2016), Improving photosynthesis and crop productivity by accelerating recovery from photoprotection. Science, 354 (6314), 857-861.

11. Menossi, M., Silva-Filho, M.C., Vincentz, M., Van-Sluys, M.A., Souza, G.M., (2008), Sugarcane functional genomics: gene discovery for agronomic trait development. International Journal of Plant Genomics, 2008, 458732. 


\title{
BÀI BÁO KHOA HỌC
}

\section{TECHNOLOGICAL APPLICATION IN AGRICULTURE IN THE NORTH-CENTRAL REGION IN THE CONTEXT OF CLIMATE CHANGE Nguyen Thi Hoang Anh', Do Hoai Nam²}

${ }^{1}$ Standing Office of National Scientific Program on Natural Resources Environment and

Climate Change, Ministry of Natural Resources and Environment

${ }^{2}$ Ministry of Science and Technology

\begin{abstract}
The North Central Coast is one of seven economic regions with a general plan for socio-economic development. However, under the impact of climate change, the economic development of the region still faces many difficulties, especially in agricultural production, so a clear orientation is needed to apply technologies to improve the quality of farming crop. This study uses a multidimensional approach, analysis, synthesis of documents, combining local analysis with interregional analysis to select priority technology in agriculture for the North Central Vietnam in the context of climate change. The results of this research can contribute to the improvement in the application of science and technology for effective agricultural production to respond to climate change in the North Central region.
\end{abstract}

Keywords: North Central, Agriculture, Science and Technology. 